\title{
Single-Chain Variable Fragment
}

National Cancer Institute

\section{Source}

National Cancer Institute. Single-Chain Variable Fragment. NCI Thesaurus. Code C63927.

A genetically eng ineered antibody consisting of both the variable heavy chain $(\mathrm{VH})$ and the light chain (VL) of an immunog lobulin. These entities are joined together by a flexible peptide linker. 